\title{
Kayseri Yeşilhisar Ekolojik Koşullarında Farklı Azotlu Gübre Kaynakları ve Dozlarının Silajlık Mısırın Bazı Verim ve Kalite Özelliklerine Etkisi
}

\author{
Şakir Murat Karagöz ${ }^{1}$ Satı Uzun ${ }^{1}$ Hamdi Özaktan ${ }^{1}$ Oğuzhan Uzun ${ }^{2} \quad$ Adem Güneş $^{2}$
}

\author{
${ }^{1}$ Erciyes Üniversitesi, Ziraat Fakültesi, Tarla Bitkileri Bölümü, Kayseri, Türkiye \\ ${ }^{2}$ Erciyes Üniversitesi, Ziraat Fakültesi, Toprak Bilimi ve Bitki Besleme Bölümü, Kayseri, Türkiye \\ Sorumlu yazar: saticocu@yahoo.com
}

$\ddot{O} \mathbf{z}$

Araştırma, Kayseri İli Yeşilhisar İlçesi ekolojik koşullarında tesadüf bloklarında faktöriyel deneme desenine göre 3 tekerrürlü olarak 2013 yılında yürütülmüştür. Araştırmada farklı azotlu gübre tipleri ve dozlarının mısırda ot verimi ve kalitesine etkisi araştırılmıştır. Bu amaçla 7,5 kg/da saf azot ekimle birlikte uygulandıktan sonra üst gübre olarak $0,7,5,15$ ve 22,5 kg/da saf azot içerecek şekilde amonyum nitrat, üre, 3,4dimetilpirazol fosfat (DMPP) inhibitörlü amonyum sülfat nitrat ve üreaz inhibitörlü üre gübreleri uygulanmıştır. Araştırma sonuçlarına göre silajlık mısırda bitki boyu 1,82-2,29 m, yaprak oranı \%19,01-22,73, sap oranı $\% 35,01-43,85$, koçan oranı \%36,49-45,26, kuru ot verimi 950-1564 kg/da, ham protein oranı \%6,88-8,61, ham protein verimi $65,25-124,71 \mathrm{~kg} / \mathrm{da}$, ADF oranı \%18,69-23,82, NDF oranı \%43,98-50,08 arasında değişim göstermiştir. Gübre çeşidi ve dozlarının ot verimi üzerine etkisi önemli bulunmuştur. Artan azot dozlarına bağlı olarak kuru ot verimleri artmıştır. Ancak 15 ve $22,5 \mathrm{~kg} / \mathrm{da} \mathrm{N}$ uygulamaları istatistiksel olarak aynı grupta yer almıştır. Gübre çeşitleri incelendiğinde ise en yüksek ortalama kuru ot verimi inhibitörlü gübrelerden elde edilmiştir.

Anahtar Kelimeler: Azot dozu, Nitrifikasyon ve üreaz inhibitörleri, Ot verimi ve kalite, Silajlık mısır

\section{The Effect of Different Nitrogen Fertilizer Sources and Doses on Some Yield and Quality Characteristics of Silage Corn in Kayseri Yeşilhisar}

\section{Abstract}

Experiments were conducted under ecological conditions of the Yeşilhisar town of Kayseri province in randomized blocks -factorial experimental design with 3 replications in the 2013 growing season. Effects of different nitrogen types and doses applied as a side-dressing fertilizer on yield and quality of silage corn were investigated in this study. Following the pure nitrogen treatment of $7.5 \mathrm{~kg} / \mathrm{da}$ in the form of $15-15-0+\mathrm{Zn}$ as base fertilizer, ammonium nitrate, urea, ammonium sulphate nitrate with a nitrification inhibitor and urea with a urease inhibitor treatments were applied as to have 0,7.5, 15 and $22.5 \mathrm{~kg} / \mathrm{da}$ pure nitrogen as a side-dressing fertilizer. According to the results; plant height, leaf ratio, stem ratio, cob ratio, dry matter yield, crude protein ratio, crude protein yield, ADF and NDF were 1.82-2.29 m, 19.01-22.73\%, 35.01-43.85\%, 36.49-45.26\%, 950$1564 \mathrm{~kg} / \mathrm{da}, 6.88-8.61 \%, 65.25-124.71 \mathrm{~kg} / \mathrm{da}, 18.69-23.82 \%, 43.98-50.08 \%$ respectively. Both the nitrogen types and doses had significant effects on dry hay yields. Increasing nitrogen doses increased hay yield. However, 15 and $22.5 \mathrm{~kg} / \mathrm{da} \mathrm{N}$ treatments were in the same statistical group. With regard to type of fertilizer, ammonium sulphate nitrate with 3,4-dimethylepyrazole phosphate and urea with NBPT had the greatest yield.

Key words: Nitrogen dose, Nitrification and urease inhibitors, Forage yield and quality, Silage corn

\section{Giriş}

Azot, bitkilerde klorofilin, proteinlerin, aminoasitlerin, nükleik asitlerin yapı taşı olduğundan bitkilerde fotosentez gibi önemli fizyolojik olaylarda görev alan ve bitkisel üretimi etkileyen, bitkisel üretimde en fazla ihtiyaç duyulan makro besin elementlerinden birisidir. Dünyada üretim sistemlerinde bitkilerin ihtiyaç duyduğu azot büyük oranda kimyasal gübrelerden sağlanırken üretilen azotlu gübrelilerin yaklaşık \%50'si üç önemli tahıl olan çeltik, buğday ve mısırın üretiminde kullanılmaktadır (Ladha ve ark., 2016). Azotlu gübreler tarımda en pahalı girdilerden olup yılda yaklaşık maliyeti 50 milyar dolar civarındadır (Ladha ve Chakraborty, 2016). Ancak ne yazık ki, azotlu gübreler tarımda çok etkin bir şekilde kullanılmamakta ve bitki-toprak sisteminde geri kazanımı nadiren \%50'yi geçmektedir (Abbasi ve ark., 2013). Büyük oranda yıkanma, denitrifikasyon, volatilizasyon, toprak erozyonu ve immobilizasyonla kayba uğramaktadır. Bu nedenle bitkisel üretimde azot kayıplarını 
azaltabilmek için özel tip gübreler geliştirmiştir. Bu özel tip gübreler yaprak gübreleri, yavaş ve kontrollü salınımlı gübreler ile stabilize gübreler olarak sıralanabilir (Trenkel, 2010). Stabilize gübreler içerisinde yer alan nitrifikasyon inhibitörleri toprakta Nitrosomonas bakterilerinin aktivitelerini 4-10 hafta arasında baskılayarak amonyum iyonlarının oksidasyonunu geciktirmektedir. Nitrifikasyon inhibitörlerinin kullanımı toprakta azotun amonyum halinde daha uzun süre kalmasına neden olarak yıkanma ile nitrat kayıplarını veya denitrifikasyon ile nitros oksit üretimini kontrol etmekte ve böylece azot kullanım etkinliğini artırmaktadır. Bir nitrifikasyon inhibitörü olan 3,4dimetilpirazol fosfat (DMPP) özellikle amonyum sülfat nitrat, amonyum nitrat ve üre gibi katı mineral gübrelere katılmaktadır. Yapılan çalışmalarda DMPP inhibitörünün gaz halinde ve nitrat yıkanması kayıplarını azalttığı bildirilmektedir (Linzmeier ve ark., 2001; Wu ve ark., 2007; Liu ve ark., 2013; Martinez-Alcantara ve ark., 2013).

Üre hızlı bir şekilde hidrolize olan bir gübredir ve toprağa uygulandığı zaman üreaz enzimi yoluyla hızla hidroliz olarak $\mathrm{NH}_{4}$ oluşur. Toprak yüzeyine üre uygulaması ile amonyak şeklinde azot kayb1 \%50'leri bulabilmektedir (Bellitürk ve ark., 2007). Üreaz inhibitörleri ürenin amonyuma dönüşümünü gerçekleştiren üreaz enzim aktivitesini kontrol ederek etki göstermektedir. Bu nedenle üreaz inhibitörlü üre kullanımı ile amonyak şeklinde azot kayıpları engellenebilmektedir. En çok kullanılan üreaz inhibitörü N-(n-butyl) thiophosphorictriamide (NBPT)'dir (Motavalli ve ark., 2008). NBPT'nin üre hidrolizini önlenme süresi toprak pH'sına ve sıcaklığa bağlı olarak değişmektedir (Carmona ve ark., 1990; Watson ve ark., 1994).

Misır C4 bitkisi olması nedeniyle birim alanda fazla miktarda kuru madde üreten bir bitkidir. $\mathrm{Bu}$ nedenle iyi ve dengeli bir şekilde gübrelenmesi gerekmektedir. Mısır bitkisinin özellikle N ihtiyacı fazladır (İptaş, 2008). Binder ve ark. (2000)'nin Hanway (1963)'tan bildirdiğine göre mısırın azot alımı vejetatif gelişmenin ortasında artmakta ve püskül çıkarma öncesinde maksimum azot alımı gerçekleşmektedir. Püskül oluşumuna kadar olan gelişme döneminde toprakta yeterli azot bulunması verim açısından oldukça önemlidir. Bu araştırmada, iki farklı inhibitörlü gübre ile iki farklı klasik gübrenin farklı dozlarının üst gübre olarak silajlık mısırda verim ve verim öğeleri ile kalite özellikleri üzerine etkisi incelenmiştir.

\section{Materyal ve Yöntem}

Araştırmada Syngenta firmasına ait NK Antria mısır çeşidi kullanılmıştır. Antria mısır çeşidi silaj kalitesi ve verimi yüksek, koçan verimi bakımından verimli bir mısır çeşididir. Bu araştırma, 2013 y1lı bitkisel üretim döneminde Kayseri İli Yeşilhisar İlçesi Kılcan mevkiinde bulunan arazide yürütülmüş̧ür. Deneme alanının 0-30 cm derinliğinden alınan toprak numunesinin yapılan analizlerine ait sonuçlar Çizelge 1'de verilmiştir. Toprak analizi neticelerine göre deneme alanında toprağın bünyesi tınlı, alkali reaksiyona sahip, tuzsuz sinıfta yer almaktadır.

Denemenin yürütüldüğü 2013 yılına ait bazı iklim verileri Çizelge 2'de verilmiştir. Denemenin yürütüldüğü mayıs, haziran, temmuz ve ağustos aylarında ortalama maksimum ve minimum sıcaklıklar 25.24-39.90 ve $12.48-16.04{ }^{\circ} \mathrm{C}$ arasında değişim göstermiştir.

Çalışma tesadüf bloklarında faktöriyel deneme desenine göre 3 tekerrürlü olarak yürütülmüştür. Denemede 4 farklı azotlu gübre çeşidi (amonyum nitrat, üre, ENTEC 26 ticari isimli DMPP inhibitörlü amonyun nitrat sülfat ve UTEC 46 ticari isimli NBPT inhibitörlü üre) ve 4 farkl1 azot dozu $(0,7,5,15$ ve 22,5 kg/da N) kullanılmıştır. Ekimde önce bütün parsellere 7,5 kg/da N 15-15$0+Z n$ gübresi ile verilmiş ve kültivatör ile toprağa karıştırılmıştır. Denemede, her blok 13 parsel ve parsel boyu 3 m'dir. Her parsel arasında $70 \mathrm{~cm}$ ve bloklar arasında ise $1 \mathrm{~m}$ mesafe bırakılmıştır. Parsellere $70 \mathrm{~cm}$ 'ye ayarlı el markörü ile 6 çizi açılmış, sıralara her $20 \mathrm{~cm}$ 'de 2 tohum gelecek şekilde elle 11 Mayıs 2013 tarihinde ekim yapılmış, ekimden sonra deneme alanı yağmurlama sulama sistemi ile sulanmış ve çıkışlardan sonra tekleme işlemi gerçekleştirilmiştir. Ekimden yaklaşık 35 gün sonra $7,5 \mathrm{~kg} / \mathrm{da}$ başlangıç azotunun üzerine $0,7,5,15$ ve $22,5 \mathrm{~kg} / \mathrm{da}$ azot (N0, N7.5, N15 ve N22.5) belirtilen gübreler sıra aralarına üstten serpme olarak verilmiş ve ardından deneme alanı sulanmıştır. Daha sonra boğaz doldurma işlemi yapılmıştır. Bitkilerin su ihtiyacı göz önüne alınarak deneme alanı haftada bir defa sulanmıştır. Hasat 26.08.2013 tarihinde hamur olum dönemi başlangıcında elle yapılmışıtır. Hasat sırasında tesadüfi seçilen 10 bitkide bitki boyu, yine hasat döneminde her parselden rastgele alınan 3 bitkide yaprak, sap ve koçan ayrılarak $70^{\circ} \mathrm{C}$ 'de sabit ağırlığa ulaşıncaya kadar kurutulmuş ve ayrı ayrı tartılmış tüm bitki ağırlığına oranlanarak yaprak, sap ve koçan oranları belirlenmiştir. Her parselden 
kenar tesiri çıarıldıktan sonra geriye kalan alandan biçilen 10 bitkinin yeşil aksamın tartımları yapılmış kuru ot oranı ile çarpılarak kuru ot verimleri hesaplanmıştır. Her parselden alınan örnekler sabit ağırlığa gelinceye kadar kurutulduktan sonra $1 \mathrm{~mm}$ 'lik elekten geçecek şekilde değirmende öğ̈̈tülerek analize hazır hale getirilmiştir. Örneklerin azot içeriği Kjeldahl yöntemi ile belirlenmiştir. Elde edilen \% azot değerleri 6,25 katsayısı ile çarpılarak ham protein oranı belirlenmiştir. Ayrıca kuru otta NDF (Van Soest ve Wine, 1967) ve ADF (Van Soest, 1963) ANKOM 200 Fiber Analyzer (ANKOM Technology Corp. Fairport, NY, USA) cihazı kullanılarak belirlenmiştir.

Çalışmadan elde edilen veriler bilgisayarda "SPSS for Windows" programı ile tesadüf blokları faktöriyel deneme desenine göre varyans analizine tabi tutulmuştur. Muamele ortalamaları Duncan testi ile karşılaş̧ırılmıştır.

Çizelge 1. Deneme alanı topraklarına ait bazı fiziksel ve kimyasal özellikler

\begin{tabular}{|l|l|l|l|}
\hline \multicolumn{1}{|c|}{ Özellik } & Değeri & Özellik & Değeri \\
\hline $\mathrm{pH}$ (saturasyonda) & 8,13 & Kireç (\%) & 5,71 \\
\hline EC (saturasyonda) & 1,05 & Fosfor $(\mathrm{kg} / \mathrm{da})$ & 7,80 \\
\hline Su İle Doymuşluk & 45,1 & Potasyum $(\mathrm{kg} / \mathrm{da})$ & 309,04 \\
\hline Toplam Tuz $(\%)$ & 0,030 & Organik madde $(\%)$ & 1,48 \\
\hline
\end{tabular}

Analizler Yeşilhisar Ziraat Odası Toprak Bitki Analiz Laboratuvarlarında yapılmıştır.

Çizelge 2. Deneme alanının 2013 yılına ait bazı iklim verileri

\begin{tabular}{|c|c|c|c|c|c|}
\hline AYLAR & $\begin{array}{c}\text { Ortalama } \\
\text { Sıcaklık }\left({ }^{\circ} \mathbf{C}\right)\end{array}$ & $\begin{array}{c}\text { Maksimum } \\
\left.\text { Sicaklık } \mathbf{(}^{\circ} \mathbf{C}\right)\end{array}$ & $\begin{array}{c}\text { Minumum Sicaklık } \\
\left({ }^{\circ} \mathbf{C}\right)\end{array}$ & $\begin{array}{c}\text { Oransal Nem } \\
(\mathbf{\%})\end{array}$ & $\begin{array}{c}\text { Toplam } \\
\text { Yağı̧ (mm) }\end{array}$ \\
\hline MAYIS & 19,09 & 25,24 & 12,48 & 42,23 & 11,5 \\
\hline HAZİRAN & 21,6 & 39,90 & 14,46 & 40,28 & 6,5 \\
\hline TEMMUZ & 23,00 & 29,57 & 16,04 & 35,93 & 0,0 \\
\hline AĞUSTOS & 23,35 & 30,17 & 15,88 & 33,99 & 0,0 \\
\hline
\end{tabular}

*İklim verileri Kayseri Meteoroloji Müdürlüğünden alınmıştır

\section{Bulgular ve Tartışma \\ Bitki Boyu}

Yapılan varyans sonucunda bitki boyu üzerine azot dozlarının ve azotlu gübre çeşitlerinin etkisi \%1 düzeyinde önemli bulunmuştur. Çizelge 3'de görüldügü gibi mısırda bitki boyu $1.82 \mathrm{~m}$ ile $2.29 \mathrm{~m}$ arasında değişim göstermiştir. Azot dozlarına ait ortalama değerler incelendiğinde en yüksek bitki boyu 2,20 m ile N22.5 uygulamasından elde edilirken N15 ve N7.5 uygulamaları ile ayn1 istatistiksel grupta yer almıştır. En düşük bitki boyu ise N0 uygulamasında elde edilmiştir. Gübre çeşitleri incelendiğinde ise en yüksek bitki boyu DMPP inhibitörlü ASN ve üreaz inhibitörlü üre uygulamalarından en düşük ise amonyum nitrat ve üre uygulamalarından elde edilmiştir. Araştırma sonucunda elde edilen bitki boyu değerleri Erdal ve ark. (2009), Çelebi ve ark. (2010a, 2010b)'nin silajlık misırda elde ettiği değerlerle benzerlik göstermektedir.

Çizelge 3. Farklı azotlu gübre ve dozlarında yetiştirilen silajlık mısırda ortalama bitki boyu değerleri (m)

\begin{tabular}{|c|c|c|c|c|c|}
\hline \multirow{2}{*}{ Azot Dozu } & \multicolumn{5}{|c|}{ Azotlu Gübre Çeşidi } \\
\cline { 2 - 6 } & AN & Üre & DMPP+ASN & NBPT+üre & Ortalama \\
\hline N0 & 1,82 & 1,82 & 1,82 & 1,82 & $\mathbf{1 , 8 2} \mathbf{b}^{*}$ \\
\hline N7.5 & 2,07 & 2,10 & 2,27 & 2,16 & $\mathbf{2 , 1 5}$ a \\
\hline N15 & 2,11 & 2,11 & 2,27 & 2,28 & $\mathbf{2 , 1 9}$ a \\
\hline N22.5 & 2,14 & 2,14 & 2,29 & 2,27 & $\mathbf{2 , 2 0}$ a \\
\hline Ortalama & $\mathbf{2 , 0 4} \mathbf{b}^{*}$ & $\mathbf{2 , 0 4} \mathbf{b}$ & $\mathbf{2 , 1 6}$ a & $\mathbf{2 , 1 3}$ a & \\
\hline
\end{tabular}

*: Aynı sütunda ve satırda farklı küçük harflerle gösterilen ortalamalar arasındaki fark $\mathrm{P}<0.05$ düzeyinde önemlidir 


\section{Yaprak, Sap, Koçan Oranı:}

Yaprak oranı üzerine azotlu gübre çeşitlerinin ve azot dozu uygulamalarını etkisi $\% 5$ düzeyinde önemli bulunurken, sap ve koçan oranı üzerine sadece azot dozlarının etkisi \%1 düzeyinde önemli bulunmuştur. Denemede yaprak oranı değerleri \%19,01 ile $\% 22,73$, sap oranı değerleri $\% 35,01$ ile \%43,85 ve koçan oranı değerleri \%36,49 ile \%45,26 arasında değişim göstermiştir. Azot dozlarına ait ortalama değerler incelendiğinde en yüksek yaprak oranı değeri N7,5 uygulamasından elde edilirken N22.5 ve N15 uygulamaları da aynı istatistiksel gruba girmiştir. En düşük yaprak oranı değeri ise N0 (kontrol grubu) uygulamasından elde edilmiştir. Gübre çeşitleri incelendiğinde ise en yüksek değer $(\% 21,43)$ üre gübresinde belirlenmiştir. En yüksek sap oranı N0 uygulamasından elde edilirken, en yüksek koçan oranı N15 uygulamasından elde edilmiştir ve istatistiksel olarak N22,5 uygulaması ile aynı gruba girmiştir (Çizelge 4).

Çizelge 4. Farklı azotlu gübre ve dozlarında yetiştirilen silajlık mısırda ortalama yaprak, sap ve koçan oranı değerleri (\%)

\begin{tabular}{|c|c|c|c|c|c|}
\hline \multirow[b]{2}{*}{ Azot Dozu } & \multicolumn{5}{|c|}{ Azotlu Gübre Çeşidi (Yaprak oranı) } \\
\hline & $\mathbf{A N}$ & Üre & DMPP+ASN & NBPT+üre & Ortalama \\
\hline No & 19,67 & 19,67 & 19,67 & 19,67 & $19,67 b^{*}$ \\
\hline N7.5 & 22,49 & 21,10 & 20,69 & 20,61 & 2122 a \\
\hline N15 & 20,19 & 22,21 & 19,01 & 20,90 & $20,58 \mathrm{ab}$ \\
\hline $\mathrm{N} 22.5$ & 21,08 & 22,73 & 20,38 & 20,03 & 21,06 a \\
\hline \multirow[t]{2}{*}{ Ortalama } & $20,86 \mathbf{a b}^{*}$ & 21,43 a & $19,94 \mathrm{~b}$ & $20,30 \mathrm{ab}$ & \\
\hline & \multicolumn{5}{|c|}{ Sap oranı } \\
\hline N0 & 43,85 & 43,85 & 43,85 & 43,85 & $43,85 \mathrm{a}^{*}$ \\
\hline N7.5 & 37,26 & 39,38 & 38,29 & 36,47 & 37,85 b \\
\hline N15 & 35,32 & 37,00 & 35,73 & 35,50 & $35,89 \mathrm{c}$ \\
\hline $\mathrm{N} 22.5$ & 35,01 & 35,52 & 35,56 & 36,91 & $35,75 \mathrm{c}$ \\
\hline \multirow[t]{2}{*}{ Ortalama } & 37,86 & 38,94 & 38,35 & 38,18 & \\
\hline & \multicolumn{5}{|c|}{ Koçan oranı } \\
\hline No & 36,49 & 36,49 & 36,49 & 36,49 & $36,49 c^{*}$ \\
\hline N7.5 & 40,26 & 39,51 & 41,02 & 42,92 & $40,93 \mathrm{~b}$ \\
\hline N15 & 44,48 & 40,79 & 45,26 & 43,61 & 43,54 a \\
\hline $\mathrm{N} 22.5$ & 43,91 & 41,75 & 44,06 & 43,05 & 43,19 a \\
\hline Ortalama & 41,28 & 39,64 & 41,71 & 41,52 & \\
\hline
\end{tabular}

*: Aynı sütunda farklı küçük harflerle gösterilen ortalamalar arasındaki fark $\mathrm{P}<0.05$ düzeyinde önemlidir

Silajlık mısır tarımında ot verimi ve besleme değerinin önemli bir kısmı koçandan gelmektedir (Öztekin 2007). Bu nedenle hasat zamanında bitkinin koçan bağlamış olması ve yüksek koçan oranı oldukça önemlidir. Bu araştırma sonucunda kuru ağırlık cinsinden bitkide azot uygulamalarına bağlı olarak sap oranının azaldığı, koçan oranının arttığı belirlenmiştir (Çizelge 4). Çelebi ve ark (2010a)'nın Van ekolojik koşullarında TTM-815 silajlı mısır çeşitleri ile yürüttükleri denemede koçan oranının artan azot dozlarına bağlı olarak artış gösterirken, sap oranının bir azalma gösterdiğini, yaprak oranının ise kısmen sabit kaldığını, sap oranı en yüksek değerine azotlu gübre uygulaması yapılmayan parsellerde ulaşırken, aynı parsellerde koçan oranının en düşük değerlerde bulunduğunu tespit etmişlerdir. Akar ve ark. (2014), mısırda toprakta yeterli azotun bulunmadığı durumda bitkinin erken çiçeklenmeye zorlandığını ve büyüme süresinin kısaldığını sonuç olarak koçanın uç kısmında çok az tane oluştuğunu bildirmektedir.

\section{Kuru ot verimi}

Kuru ot verimi üzerine azot dozlarının ve azotlu gübre çeşitlerinin etkisi varyans analizi sonuçlarına göre \%1 düzeyinde önemli bulunmuştur. Araştırmada kuru ot verimi değerleri $950 \mathrm{~kg} / \mathrm{da}$ ile $1564 \mathrm{~kg} / \mathrm{da}$ arasında değişim göstermiştir. Azot dozlarına ait ortalama değerler incelendiğinde en yüksek kuru ot verimi N15 uygulamasından elde edilmekle birlikte N22.5 uygulamas1 da ayn1 istatistiksel grupta yer almıştır. En düşük ise üst gübre uygulanmayan N0 uygulamasında 
belirlenmiştir. N0 dozunda $950 \mathrm{~kg} / \mathrm{da}$, N7.5 dozunda $1375 \mathrm{~kg} / \mathrm{da}$, N15 dozunda $1495 \mathrm{~kg} / \mathrm{da}$ ve N22.5 dozunda ise $1488 \mathrm{~kg} /$ da kuru ot verimi elde edilmiştir.

Elde edilen kuru ot verimleri Yılmaz ve Sağlamtimur (1996)'un Çukurova, Çelebi ve ark. (2010b)'nın Van, Kaplan ve ark. (2016)'nın Kayseri ve Özata ve Kapar (2017)'ın Samsun-Çarşamba ekolojik koşullarında yürüttükleri denemelerde elde ettikleri sonuçlara benzer bulunmuştur. Farklı ekolojik koşullarda farklı mısır çeşitleri ile yürütülen çalışmalarda artan azot dozlarına bağlı olarak mısırda ot veriminin arttığı bildirilmektedir (Budaklı-Çarpıcı ve ark., 2010; Öztekin, 2007; Kaplan ve ark., 2016). Misırda en yüksek ot verimini, Yılmaz ve Sağlamtimur (1996) 16 ve $22 \mathrm{~kg} / \mathrm{da}$, Budakl1Çarpıc1 ve ark. (2010) $30 \mathrm{~kg} / \mathrm{da}$, Çelebi ve ark. (2010b) $20 \mathrm{~kg} / \mathrm{da}$ ve Kaplan ve ark. (2016) ise $30 \mathrm{~kg} / \mathrm{da}$ azot uygulamalarından elde etmişlerdir. Çalışmalar arasında optimum azot dozu bakımından gözlenen farklılıklar çevre koşullarından ya da kullanılan çeşitten kaynaklanmış olabilir.

Çizelge 5. Farklı azotlu gübre ve dozlarında yetiştirilen silajlık mısırda kuru ot verimi değerleri $(\mathrm{kg} / \mathrm{da})$

\begin{tabular}{|l|c|c|c|c|c|}
\hline \multirow{2}{*}{ Azot Dozu } & \multicolumn{5}{|c|}{ Azotlu Gübre Çeşidi } \\
\cline { 2 - 6 } & AN & Üre & DMPP+ASN & NBPT+üre & Ortalama \\
\hline N0 & 950 & 950 & 950 & 950 & $\mathbf{9 5 0} \mathbf{c}^{*}$ \\
\hline N7.5 & 1299 & 1322 & 1514 & 1365 & $\mathbf{1 3 7 5} \mathbf{b}$ \\
\hline N15 & 1405 & 1450 & 1564 & 1561 & $\mathbf{1 4 9 5} \mathbf{a}$ \\
\hline N22.5 & 1442 & 1430 & 1517 & 1563 & $\mathbf{1 4 8 8}$ a \\
\hline Ortalama & $\mathbf{1 2 7 4}^{*}$ & $\mathbf{1 2 8 8} \mathbf{b}$ & $\mathbf{1 3 8 6} \mathbf{a}$ & $\mathbf{1 3 6 0}$ a & \\
\hline
\end{tabular}

*: Aynı sütunda ve satırda farklı küçük harflerle gösterilen ortalamalar arasındaki fark $\mathrm{P}<0.05$ düzeyinde önemlidir

Gübre çeşitleri değerlendirildiğinde, en yüksek ortalama kuru ot verimi DMPP inhibitörlü ASN ve NBPT+üre gübrelerinde tespit edilmiştir. Amonyum nitrat, üre, üreaz inhibitörlü üre ve DMPP inhibitörlü ASN gübrelerinde sırasıyla ortalama 1274, 1288, 1360 ve $1386 \mathrm{~kg} /$ da kuru ot verimi elde edilmiştir. İpek (2016) mısırda NBPT kaplı ürenin normal üreye göre silaj verimini artırdığını, Pasda ve ark. (2001) tane mısırda DMPP'li ASN uygulamasının, ASN'ye göre tane verimini hektara 0,24 ton artırdığını belirlemişlerdir. Abalos ve ark. (2014)'de yaptıkları meta-analizi sonucunda inhibitörlü gübrelelerin (DMPP, DCD ve NBPT) ürün verimini ve azot kullanım etkinliğini, sırasıyla ortalama $\% 7,5$ ve $\% 12,9$ oranında artırdığını, etkinliklerinin çevre ve yönetim faktörlerine bağlı olduğunu özellikle kaba dokulu, alkali ve sulanan sistemlerde daha etkili oldukları ancak bu inhibitörlerin üreticiye ekstra maliyet yüklediğini bu nedenle etkinliklerini maksimum seviyeye getirmek için daha fazla araştırmaya ihtiyaç olduğunu ifade etmiştir.

\section{Ham Protein Oranı ve Verimi}

Ham protein oranı ve verimi üzerine sadece azot dozlarının etkisi \%1 düzeyinde önemli bulunmuştur.

Çizelge 6. Farklı azotlu gübre ve dozlarında yetiştirilen silajlık mısırda ortalama ham protein oranı ve verimi değerleri

\begin{tabular}{|c|c|c|c|c|c|}
\hline \multirow[b]{2}{*}{ Azot Dozu } & \multicolumn{5}{|c|}{ Azotlu Gübre Çeşidi (Ham protein oranı, \%) } \\
\hline & $\mathbf{A N}$ & Üre & DMPP+ASN & NBPT+üre & Ortalama \\
\hline No & 6,88 & 6,88 & 6,88 & 6,88 & $6,88 d^{*}$ \\
\hline N7.5 & 7,57 & 7,43 & 7,11 & 7,11 & 7,31 c \\
\hline N15 & 7,96 & 7,79 & 7,98 & 7,34 & $7,77 \mathrm{~b}$ \\
\hline $\mathrm{N} 22.5$ & 8,04 & 8,61 & 7,96 & 7,89 & 8,13 a \\
\hline \multirow{2}{*}{ Ortalama } & 7,61 & 7,69 & 7,48 & 7,31 & \\
\hline & \multicolumn{5}{|c|}{ Ham protein verimi $(\mathrm{kg} / \mathrm{da})$} \\
\hline No & 65,25 & 65,25 & 65,25 & 65,25 & 65,25 c \\
\hline N7.5 & 98,07 & 98,28 & 107,68 & 96,94 & $100,24 \mathrm{~b}$ \\
\hline N15 & 111,86 & 113,03 & 124,71 & 114,65 & 116,06 a \\
\hline $\mathrm{N} 22.5$ & 116,05 & 122,53 & 120,75 & 123,22 & 120,64 a \\
\hline Ortalama & $\mathbf{9 7 , 8 1}$ & 99,77 & 104,60 & 100,01 & \\
\hline
\end{tabular}

*: Aynı sütunda farklı küçük harflerle gösterilen ortalamalar arasındaki fark $\mathrm{P}<0,05$ düzeyinde önemlidir 
Deneme sonucunda silajlık mısırda ham protein oranı değerleri \%6,88 ile \%8,61 arasında değişim göstermiştir. Azot dozlarına ait ortalama değerler incelendiğinde en yüksek ham protein oranı $\% 8,13$ ile N22,5 uygulamasından en düşük ise \%6,88 ile N0 uygulamasından elde edilmiştir. Artan azot dozlarına bağlı olarak ham protein oranları artmıştır ancak gübre kaynağının etkisi protein oranını etkilememiştir. Elde edilen bulgular Yılmaz ve Sağlamtimur (1996) ve Safdarian ve ark. (2014) ile benzerlik göstermektedir. Yılmaz ve Sağlamtimur (1996) ve Safdarian ve ark. (2014) kullanılan azot kaynağının protein oranına etkisi olmadığını ancak artan azot dozları ile bitkide protein miktarının arttığını bildirmektedir. Çelebi ve ark. (2010) Van ekolojik koşullarında yürüttükleri çalışmada ham protein oranı ortalama $\% 6,7$ ile $\% 7,7$ arasında değiştiğini azot dozları, azot formları ve doz x form interaksiyonun etkisinin önemli olduğunu, azot formları açısından en düşük ham protein oranının üre uygulamasından elde edildiğini tespit etmişlerdir. Amin (2011)'de benzer şekilde en düşük protein oranının üre uygulamasında belirlemişledir. Yozgatlı ve ark. (2019) ham protein içeriğinin genetik kontrol düzeyi yüksek bir özellik olmakla birlikte iklim, ekim zamanı, hasat zamanı, yetiştirme tekniği ve gübreleme gibi birçok çevre faktöründen de büyük ölçüde etkilendiğini bildirmektedir. Farklı araştırıcılar tarafından elde edilen farklı sonuçlar bu durumdan kaynaklanmış olabilir.

Çizelge 6 incelendiğinde en yüksek ham protein verimi N22,5 uygulamasından elde edilmiş ve N15 uygulaması ile aynı istatistiksel grupta yer almıştır. N0 uygulamasında $65,25 \mathrm{~kg} / \mathrm{da}$ ham protein verimi kaydedilirken N7,5, N15 ve N 22,5 uygulamalarında sirasıyla 100,24, 116,06 ve 120,64 kg/da ham protein verimi kaydedilmiştir. Uygulanan azot dekara protein verimini Çelebi ve ark. (2010a, 2010b), Öztekin (2007)'nin de belirttiği gibi önemli ölçüde artırmıştır.

\section{oranları}

Nötr Deterjanda Çözünmeyen Lif (NDF) ve Asit Deterjanda Çözünmeyen Lif (ADF)

NDF oranı üzerine sadece azot dozu uygulamaları \%5 düzeyinde önemli bulunurken, ADF oranı üzerine azot dozu uygulamalarının etkisi \%1 düzeyinde, azotlu gübre çeşidi ve interaksiyonun etkisi ise (Azotlu gübre ç̧eşidi x Azot dozu) \%5 düzeyinde önemli bulunmuştur.

Çizelge 7. Farklı azotlu gübre ve dozlarında yetiștirilen silajlık mısırda NDF ve ADF oranları (\%)

\begin{tabular}{|c|c|c|c|c|c|}
\hline \multirow[t]{2}{*}{ Azot Dozu } & \multicolumn{5}{|c|}{ Azotlu Gübre Çeșidi (NDF) } \\
\hline & $\mathbf{A N}$ & Üre & DMPP+ASN & NBPT+üre & Ortalama \\
\hline No & 49,38 & 49,38 & 49,38 & 49,38 & $49,38 \mathrm{a}^{*}$ \\
\hline N7.5 & 48,22 & 47,72 & 50,08 & 50,06 & 49,02 a \\
\hline N15 & 47,44 & 48,17 & 43,98 & 45,98 & $46,39 \mathrm{~b}$ \\
\hline $\mathrm{N} 22.5$ & 47,69 & 44,33 & 45,05 & 48,75 & $46,47 \mathrm{~b}$ \\
\hline \multirow[t]{2}{*}{ Ortalama } & 48,18 & 47,40 & 47,12 & 48,54 & \\
\hline & \multicolumn{5}{|c|}{ ADF } \\
\hline No & $23,73 \mathrm{a}$ & $23,73 \mathrm{a}$ & $23,73 \mathrm{a}$ & $23,73 \mathrm{a}$ & 23,73 a \\
\hline N7.5 & $21,22 b c$ & $22,48 \mathrm{ab}$ & $23,48 \mathrm{a}$ & $23,82 \mathrm{a}$ & $22,75 \mathrm{~b}$ \\
\hline N15 & $20,73 \mathrm{c}$ & $20,97 \mathrm{~b}$ & $20,92 \mathrm{~b}$ & $22,33 \mathrm{a}$ & $21,24 \mathrm{c}$ \\
\hline N22.5 & $23,12 \mathrm{ab}$ & $18,69 \mathrm{c}$ & $23,23 \mathrm{a}$ & $21,88 \mathrm{a}$ & 21,73 bc \\
\hline Ortalama & 22,20 a & $21,47 \mathrm{ab}$ & 22,84 a & 22,94 a & \\
\hline
\end{tabular}

*: Aynı sütunda ve satırda farklı küçük harflerle gösterilen ortalamalar arasındaki fark $\mathrm{P}<0.05$ düzeyinde önemlidir

Karbonhidratlar mısır bitkisinin kimyasal bileşiminde önemli bir yere sahiptir ve yapısal ve yapısal olmayan karbonhidratlar olmak üzere ikiye ayrılmaktadır. Yapısal karbonhidratlar NDF (hemiselüloz+selüloz+lignin), ADF (selüloz+lignin) ve ADL (lignin) olarak gruplandırılmaktadır (Milasinovic-Seremesic ve ark., 2017). NDF ve ADF, yemlerin tüketilebilirliğinin ve sindirilebilirliğinin tahmin edilmesinde yaygın olarak kullanılmaktadır (Tekce ve Gül, 2014). Misır kuru otunda NDF oranı \%44,33-50,08, ADF oranı \%18,69-23,82 arasında değişim göstermiştir. Araştırma sonucunda ADF oranına ait belirlenen değerler Kaplan ve ark. (2016) ve Budaklı-Çarpıcı ve ark. (2017) ile uyumlu Özata ve Kapar (2017) ve Budaklı-Çarpıcı ve ark. (2010)'dan düşük bulunmuştur. Okan (2015) silajlık mısırda farklı araştırıcılar tarafindan elde edilen farklı sonuçların kullanılan çeşitlerden ya da denemenin yürütüldüğü çevre faktörlerinden kaynaklanmış olabileceğini 
ifade etmiştir. Artan azot dozlarına bağlı olarak NDF ve ADF oranları düşüş göstermiştir. Benzer şekilde Safdarian ve ark. (2014), Koç ve Çalışkan (2016) ve Amin (2011) azotlu gübre uygulamasının NDF ve ADF oranını düşürdüğünü bildirmektedir.

Günümüzde sürdürülebilir tarımın önemi ve birim alan veriminin arttırılabilmesi adına elde edilen sonuçlar ışığında önemli bulgulara ulaşılmıştır. Elde edilen tek yıllık sonuçlardan yola çıkarak Yeşilhisar ekolojik koşullarında silajlık mısır bitkisi yetiştiriciliğinde $15 \mathrm{~kg} / \mathrm{da}$ saf azot olacak şekilde üst gübre uygulanması önerilebilir. Denemede kullanılan farklı tip azotlu gübrelerden DMPP inhibitörlü ASN ve üreaz inhibitörlü üre gübreleri incelenen kriterlerin birçoğunda diğer gübrelere göre üstünlük sağladığından kullanımı önerilebilir. Ancak denemenin farklı yıllarda ve lokasyonlarda yürütülerek ekonomik analizinin de yapılması sonuçların daha etkili yorumlanması açısından önemli olacağ1 düşünülmektedir.

\section{Teşekkür}

4819).

Bu çalışma Erciyes Üniversitesi Bilimsel Araştırma Projeleri tarafından desteklenmiştir. (Proje No: FYL-2014-

\section{Bilgilendirme}

Bu çalışma Erciyes Üniversitesi Fen Bilimleri Enstitüsü Tarla Bitkileri Anabilim Dalı Öğrencisi Şakir Murat Karagöz'ün Yüksek Lisans tez çalışmasından türetilmiştir.

\section{Kaynakça}

Abbasi, M.K., Tahir, M.M., Rahim, N., 2013. Effect of $\mathrm{N}$ fertilizer source and timing on yield and $\mathrm{N}$ use efficiency of rainfed maize (Zea mays L.) in Kashmir-Pakistan. Geoderma, 195, 87-93.

Abalos, D., Jeffery, S., Sanz-Cobena, A., Guardia, G., Vallejo, A., 2014. Meta-analysis of the effect of urease and nitrification inhibitors on crop productivity and nitrogen use efficiency. Agriculture, Ecosystems \& Environment, 189, 136-144.

Akar, T. Kaplan M., Sagir, N., Gelebur, A., 2014. Effects of different liquid-manure treatments on yield and quality parameters of second-crop silage corn under reduced tillage conditions. Romanian Agricultural Research, 31, 193-203.

Amin, M.E.H., 2011. Effect of different nitrogen sources on growth, yield and quality of fodder maize (Zea mays L.). Journal of the Saudi Society of Agricultural Sciences, 10:17-23.

Bellitürk, K., Danışman, F., Yılmaz, F. 2007. Üre uygulamasının topraklarda amonyum ve nitrat oluşumuna etkisi. Ondokuz Mayis Üniversitesi Ziraat Fakültesi Dergisi, 22(1): 64-72

Budaklı Çarpıcı, E., Celik, N., Bayram, G., 2010. Yield and quality of forage maize as influenced by plant density and nitrogen rate. Turkish Journal of Field Crops, 15(2): 128-132.

Budaklı Çarpıcı, E., Kuşçu, H., Karasu, A., Öz, M., 2017. Effect of drip irrigation levels on dry matter yield and silage quality of maize (Zea mays L.). Romanian Agricultural Research, 34, 293-299.

Binder, D.L., Sander D.H., Walters D.T., 2000. Maize response to time of nitrogen application as affected by levels of nitrogen deficiency. Agronomy journal, 92: 1228-1236.

Carmona, G.C.B.C., Christianson, C.B., Byrnes, B.H., 1990. Temperature and low concentration effects of the urease inhibitor $\mathrm{N}$-(n-butyl) thiophosphoric triamide (nBTPT) on ammonia volatilization from urea. Soil Biology and Biochemistry, 22(7): 933-937.

Çelebi, R., Çelen, A.S., Zorer Çelebi, Ş., Şahar, A.K., 2010b. Farklı azot ve fosfor dozlarının mısırın (Zea mays L.) silaj verimi ve kalitesine etkisi. Selçuk Üniversitesi Selçuk Tarım ve Gıda Bilimleri Dergisi, 24(4): 16-24.

Çelebi, Z.Ş., Şahar, K.A., Çelebi, R., Çelen, E.A., 2010a. ‘TTM-815’ Mısır (Zea mays L.) çeşidinde azotlu gübre form ve dozlarının silaj verimine etkisi. Ege Üniversitesi Ziraat Fakültesi Dergisi. 47(1): 61-69 S.

Erdal, Ş., Pamukçu, M., Ekiz, H., Soysal, M., Savur, O., Toros, A., 2009. Bazı silajlık mısır çeşit adaylarının silajlık verim ve kalite özelliklerinin belirlenmesi. Akdeniz Üniversitesi Ziraat Fakültesi Dergisi, 22(1): 75-81.

Hanway, J.J., 1963. Growth stages of corn (Zea mays L.). Agronomy Journal, 55:487-492.

İptaş, S., 2008. Silajlık Mısır Yetiştiriciliği. 158-163. In: Yem bitkileri ve meraya dayalı hayvancıllk eğitimi (eds: Serin Y.) Erciyes Üniversitesi yayın No:160, Kayseri.

Kaplan, M., Baran, O., Unlüukara, A., Kale, H., Arslan, M., Kara, K., Beyzi, S.B., Konca, Y., Ulas, A., 2016. The effects of different nitrogen doses and irrigation levels on yield, nutritive value, fermentation and gas production of corn silage. Turkish Journal of Field Crops, 2(1): 100-108.

Koç, A., Çalışkan, M., 2016. Azotun silaj verimine ve silaj kalitesine etkisi. Tarla Bitkileri Merkez Araştırma Enstitüsü Dergisi, 25: 265-271. 
İpek, V.A., 2016. NBPT kaplamalı ürenin buğday ve mısırda etkinliğinin belirlenmesi. Ege Üniversitesi Fen Bilimleri Enstitüsü, Toprak Bilimi ve Bitki Besleme Anabilim Dalı, Yüksek Lisans Tezi. 52 s.

Ladha, J.K., Chackraborty, D., 2016. Nitrogen and cereal production: Opportunities for enhanced efficiency and reduced $\mathrm{N}$ loses, pp. 1-7. Proceeding of the International Nitrogen Initiative Conference, "Solutuion to improve nitrogen use efficiencey for the World", 4-8 December 2016, Melbourne, Australia.

Ladha, J.K., Tirol-Padre, A., Reddy, C.K., Cassman, K.G., Verma, S., Powlson, D.S., Pathak, H., 2016. Global nitrogen budgets in cereals: a 50-year assessment for maize, rice, and wheat production systems. Scientific Reports, 6, 19355.

Linzmeier, W., Gutser, R., Schmidhalter, U., 2001. The new nitrification inhibitor DMPP (ENTEC®) allows increased N-efficiency with simplified fertilizing strategies. In Plant Nutrition (pp. 760-761). Springer Netherlands.

Liu, C., Wang, K., Zheng, X., 2013. Effects of nitrification inhibitors (DCD and DMPP) on nitrous oxide emission, cropyield and nitrogen uptake in a wheat-maize cropping system. Biogeosciences, 10: 24272437.

Martinez-Alcantara, B., Quinones, A., Polo, C., Primo-Millo, E., Legaz, F., 2013. Use of nitrification inhibitor DMPP to improve nitrogen uptake efficiency in citrus trees. Journal of Agricultural Science, 5(2): 1-18.

Milašinović-Šeremešić, M., Radosavljević, M., Terzić, D., Nikolić, V. 2017. The utilisable value of the maize plant (biomass) for silage. Journal on Processing and Energy in Agriculture, 21(2): 86-90.

Motavalli, P.P., Goyne, K.W., Udawatta, R.P., 2008. Environmental impacts of enhanced-efficiency nitrogen fertilizers. Crop management, Doi: 10.1094/CM-2008-0730-02-RV.

Okan, M., 2015. Diyarbakır Bismil koşullarında bazı silajlık mısır çeşitlerinin verim ve kalite özelliklerinin belirlenmesi. Bingöl Üniversitesi Fen Bilimleri Enstitüsü, Yüksek Lisans Tezi, Bingöl, 77 s.

Özata, E., Kapar, H., 2017. Nitelikli saf hatlardan elde edilen silajlık hibrit mısır çeşit adaylarının verim ve kalite özelliklerinin belirlenmesi. Tarla Bitkileri Merkez Araştırma Enstitüsü Dergisi, 26 (Özel Sayı): 161-168.

Öztekin, S., 2007. İkinci ürün silajlık mısır yetiştiriciliğinde azotlu ve fosforlu gübrelemenin verim, agronomik özellikler ve NPK kapsamına etkisi. Gaziosmanpaşa Üniversitesi Fen Bilimleri Enstitüsü, Doktora Tezi, Tokat, $179 \mathrm{~s}$.

Pasda, G., Hahndel, R., Zerulla, W., 2001. Effect of fertilizer with the new nitrification inhibitor DMPP (3,4dimethylpyrazole phosphate) on yield and quality of agricultural and horticultural crops. Biology and Fertility of Soils, 34:85-97.

Safdarian, M., Razmjoo, J., Dehnavi, M.M., 2014. Effect of nitrogen sources and rates on yield and quality of silage corn. Journal of Plant Nutrition, 37(4): 611-617.

Tekce, E., Gül, M., 2014. Ruminant beslemede NDF ve ADF'nin önemi. Atatürk Üniversitesi Veteriner Bilimleri Dergisi, 9(1), 63-73.

Trenkel, M.E., 2010. Slow-and controlled-release and stabilized fertilizers: an option for enhancing nutrient use efficiency in agriculture. IFA, International fertilizer industry association.

Van Soest, P.J., Wine, R.H., 1967. The use of detergents in the analysis of fibrous feeds. IV. Determination of plant cell wall constituents. Journal of the Association of Official Analytical Chemists, (50):50-55.

Van Soest, P.J., 1994. Nutritional ecology of ruminants, 2nd ed. Cornel University Pres, pp. 476.

Wu, S.F., Wu, L.H., Sh1, Q.W., Wang, Z.Q., Chen, X.Y., Li, Y.S., 2007. Effects of a new nitrification inhibitor 3, 4-dimethylpyrazole phosphate (DMPP) on nitrate and potassium leaching in two soils. Journal of Environmental Sciences, 19(7): 841-847.

Watson, C.J., Miller, H., Poland, P., Kilpatrick, D.J., Allen, M.D.B., Garrett, M.K., Christianson, C.B., 1994. Soil properties and the ability of the urease inhibitor N-(n-butyl) thio- phosphoric triamide (nBTPT) to reduce ammonia volatilization from surface-applied urea. Soil biology and Biochemistry, 26(9): 11651171

Yılmaz, Ş., Sağlamtimur, T., 1996. Ana ürün mısırda üst gübre olarak uygulanan farklı form ve dozlarda azot gübresinin hasıl verimi ve kalitesine etkisi. MKÜ Ziraat Fakültesi Dergisi, 1(1): 113-124.

Yozgatlı, O., Başaran, U., Gülümser, E., Mut, H., Çopur Doğrusöz, M., 2019. Yozgat Ekolojisinde Bazı Mısır Çeşitlerinin Morfolojik Özellikleri, Verim ve Silaj Kaliteleri. KSÜ Tarım ve Doğa Dergisi 22(2): 170177. 